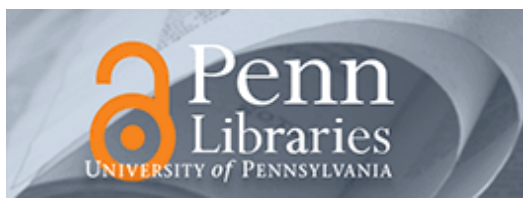

University of Pennsylvania ScholarlyCommons

Wharton Pension Research Council Working Papers

Wharton Pension Research Council

$1-1-2004$

\title{
The Case Against Stock in Public Pension Funds
}

Lawrence N. Bader

larrybader@nc.rr.com

Jeremy Gold

The Wharton School, University of Pennsylvania

Follow this and additional works at: https://repository.upenn.edu/prc_papers

Part of the Economics Commons

Bader, Lawrence N. and Gold, Jeremy, "The Case Against Stock in Public Pension Funds" (2004). Wharton Pension Research Council Working Papers. 411.

https://repository.upenn.edu/prc_papers/411

This paper is posted at ScholarlyCommons. https://repository.upenn.edu/prc_papers/411

For more information, please contact repository@pobox.upenn.edu. 


\title{
The Case Against Stock in Public Pension Funds
}

\begin{abstract}
A government has $\$ 1$ million of stock in a pension fund that covers its employees. The liability can be matched with a \$1-million dedicated bond portfolio. What are the consequences of shifting the pension fund from equities to bonds? The paragraph above duplicates the opening paragraph of The Case Against Stock in Corporate Pension Funds (Bader 2003), except that we have substituted a governmental plan for a corporate plan. Does this substitution matter?
\end{abstract}

\section{Disciplines}

Economics 


\title{
The Case Against Stock in Public Pension Funds
}

Lawrence N. Bader and Jeremy Gold

PRC WP 2004-20

\section{Pension Research Council Working Paper}

\author{
Pension Research Council \\ The Wharton School, University of Pennsylvania \\ 3620 Locust Walk, 3000 SH-DH \\ Philadelphia, PA 19104-6302 \\ Tel: 215.898.7620 Fax: 215.898.0310 \\ E-mail: prc@wharton.upenn.edu \\ http://prc.wharton.upenn.edu/prc/prc.html
}

Pension Research Council Working Papers are intended to make research findings available to other researchers in preliminary form, to encourage discussion and suggestions for revision before final publication. Opinions are solely those of the authors.

Copyright 2004 by authors. They thank Bruce Cadenhead, Tom Lowman, Bob North, Bill Sohn, and Peggy Warner for their comments and suggestions. They welcome comments and discussion forwarded to larrybader@nc.rr.com. 


\title{
The Case Against Stock in Public Pension Funds
}

\author{
Lawrence N. Bader and Jeremy Gold
}

\begin{abstract}
$\underline{\text { Abstract }}$
A government has $\$ 1$ million of stock in a pension fund that covers its employees. The liability can be matched with a \$1-million dedicated bond portfolio. What are the consequences of shifting the pension fund from equities to bonds? The paragraph above duplicates the opening paragraph of The Case Against Stock in Corporate Pension Funds (Bader 2003), except that we have substituted a governmental plan for a corporate plan. Does this substitution matter?
\end{abstract}




\section{Introduction}

Invoking a transparent accounting framework based on economics rather than actuarial and accounting traditions ${ }^{1}$, Bader (2003) concludes that shifting the corporate plan investments from equities to bonds adds value for shareholders (a tax arbitrage gain) and for participants (a benefit security gain).

Many actuaries and others believe that the Bader (2003) reasoning is irrelevant to governmental pension funds for various reasons:

- Governments have no shareholders.

- Governments pay no Federal taxes.

- The Governmental Accounting Standards Board (GASB) is not rushing towards a transparent economic accounting model.

- Taxpayers may escape a troubled local pension plan by moving, whereas corporate shareholders must find buyers for their shares.

- The indefinite lifetime of governmental pension plans suggests the possibility of intergenerational risk sharing that can deliver the equity risk premiums without commensurate risk.

Nonetheless, we show in Section 2 (risk-adjusted costs) and Section 3 (tax effects) that parallel reasoning leads to parallel conclusions: in a transparent financial environment, shifting governmental pension fund investments from equities to bonds adds value for local taxpayers (a Federal tax arbitrage gain). To the extent that the governmental pension plan has default risk, there would also be a security gain - but we ignore any such risk in this paper. We also observe that equity investment by governmental plans involves many risks besides the market risks: intergenerational taxpayer conflicts (risk transfers masquerading as risk sharing), undercharges 
to employees' compensation packages for the value of the pensions, employee claims on pension surplus, and higher governmental borrowing costs.

In Section 4 we observe that the practical obstacles to an all-bond strategy in public pension plans are greater than those that apply in a corporate setting. Nonetheless, economic analysis suggests that shunning equities helps local taxpayers in much the same ways that corporate all-bond strategies aid shareholders.

In Section 5 we consider how public plan sponsors and their actuaries can prepare for changes that will eventually follow the move towards greater transparency. Sponsors should become more cautious in granting benefits and setting investment strategies. Public plan actuaries, like their corporate brethren, must master the anti-equity reasoning (whether or not they or their clients are persuaded); ignorance will not lead to bliss.

Section 6 concludes.

\subsection{Public Pension Plans: Assumptions and Basic Illustrative Plan}

We apply the term "public pension plans" to defined benefit pension plans that cover the employees of local (state or municipal) governments. We assume that the government will not default on its pension obligations. The primary reason to pre-fund the plan, then, is to ensure that each taxpayer generation pays the full cost of the services it receives (Peskin 2001). A further goal of funding is to minimize the cost to taxpayers on an economic basis that properly accounts for risks assumed and taxes paid.

We assume complete transparency, in which

- Buyers of the government's bonds understand how the pension plan affects the value and risk of those bonds, and 
- Taxpayers recognize that their financial position includes exposure to their pro rata shares of the public plan's pension assets and liabilities.

Although taxpayers neither own the public pension plan's assets nor owe its liabilities, we may characterize their relationship to the plan's performance as exposure: we say that someone is "exposed" to a market risk (and potential reward) if that person's wealth will be greater or lesser depending on the outcome of that risk. Share ownership, for example, works exactly like this. But direct ownership is not the only kind of exposure. If, for example, "Mr. C" (the current owner of an asset) agrees to transfer the asset to "Ms. F" (the future owner) one year from now at a price set today, Ms. F is immediately exposed to the changing asset value, despite Mr. C's continuing legal title.

We recognize that real-world pension plans are not transparent - far from it. Stakeholders and decision-makers, today and in the foreseeable future, appraise these plans through dark screens that disguise risk, misvalue pension promises, and produce expedient but flawed decisions. We use the transparency assumption not to portray current reality, but rather to guide us in analyzing how public pension plans would be financed if all principals fully understood their exposure.

We initially ignore all taxes other than those paid to the local government for pension plans. In effect, each taxpayer is deemed to pay his share of the plan contributions.

We use a highly simplified example, with a single governmental employee, a single current taxpayer - Mr. C - and a single future taxpayer 20 years from now - Ms. F. For services during the current year, a portion of the employee's pay is awarded in the form of a $\$ 1,000$ lump sum payable in 20 years. This "pension" is immediately vested and is payable whether or not the employee survives for 20 years. 
Immunization. Suppose that a 20-year zero-coupon Treasury bond is currently priced to return $5 \%$ annually. Such a bond maturing for $\$ 1,000$ would cost $\$ 377$. So the government should pay the employee $\$ 377$ less in salary than it would pay in the absence of the pension promise. It can then invest $\$ 377$ in the 20-year Treasury bond, and the transaction is fair to all. The employee effectively gets a $\$ 377$ bond instead of $\$ 377$ of direct pay. Mr. C pays $\$ 377$ of taxes that cover the employee's pension; in fact, he doesn't care whether the employee receives the pension or simply receives extra pay of $\$ 377$. Ms. F, who will replace Mr. C as the sole taxpayer at some point during the next 20 years, is unaffected by the pension promise.

\section{Risk-Adjusted Plan Cost (ignoring taxes)}

In this section, we show that:

- Investing in equities does not reduce the plan cost below the immunization level (\$377). Any actuarial cost reduction based on the higher expected returns of equities is a zero-sum game across taxpayer generations. Undercharging an early generation raises the risk-adjusted cost for later generations.

- In some cases the extra cost borne by later generations provides windfalls to employees, rather than to earlier taxpayer generations.

- Once each generation's taxpayers pay the correct (immunized) cost, pension fund equity investment is no better than similar exposures in their personal portfolios.

\subsection{Does Investing in Equity Reduce the Cost of a Fixed Promise?}

Suppose that equities have an expected return of $8 \%$. Then an investment of only $\$ 215$ in equities would be expected to grow to $\$ 1,000$ in 20 years and satisfy the liability. So our current taxpayer Mr. C might prefer to pay only \$215 toward the pension and have it invested in equities. This may appear fair when we argue that twenty years is a long time, the pension plan 
seems well able to tolerate risk and, on average, the plan will meet the obligation. We will see, however, that Mr. C's apparent $\$ 162$ "saving” is really a transfer of wealth from Ms. F to Mr. C. Because the pension fund equities might earn more or less than $8 \%$, we need a method for dealing with such investment gains and losses. For now, we assume that gains and losses do not affect the employee - he will not suffer from any shortfall (the pension is certain) and he will not share in any surplus.

Suppose that Ms. F becomes responsible for all future gains and losses immediately after Mr. C pays his $\$ 215$ to the plan. At the 20 -year point, Ms. F will pay additional taxes if the plan assets are less than $\$ 1000$ and she will receive a tax rebate for any excess. On average, she will break even. How will she regard this situation at time zero?

Suppose that Ms. F has an optimal personal portfolio of equities and bonds. By this we mean that although she could expect to add return by taking on more risk, her risk preference makes any such trade-off unattractive to her.

Consider how the pension plan changes her exposure - including both her directly owned assets and her responsibility for the pension plan. By making the pension promise, the government has in effect sold a $\$ 377$ Treasury bond from her portfolio. It has also added $\$ 215$ of equities to her portfolio.

Remember that her previous position was optimal for her risk preference. That is, she would not have wanted to exchange $\$ 377$ of bonds for $\$ 377$ of equity. What the pension plan has done is far worse; it has exchanged $\$ 377$ of bonds for $\$ 215$ of equity!

How can Ms. F restore the risk level that she previously carried? She could sell $\$ 215$ of equities from her personal portfolio and pay $\$ 377$ for a zero-coupon Treasury to cover the 
pension promise. She would thereby hedge her responsibility for the governmental plan and reduce her equity exposure to its previous level. Unfortunately, she'll be out of pocket $\$ 162$.

What has happened here? The $\$ 215$ of equities was bought in the expectation of earning $3 \%$ risk premiums ( $8 \%$ expected return versus the certain $5 \%$ Treasury yield). Mr. C took credit for the expected risk premiums, but bore no risk. Ms. F bears the risk, but has no expected risk premiums. (She may win or lose, but her expected gain/loss is zero.) Risk carries a price in the markets, and the market price to dispose of Ms. F's risk is $\$ 162$. So there is no overall gain from the equity investment; the initial $\$ 162$ "saving" enjoyed by Mr. C is simply an intergenerational transfer of cost in the form of risk.

\subsection{Who Wins What Ms. F. Loses?}

Another danger to the taxpayers is the possibility of under-pricing the pension promise to the employee. If the government is funding only $\$ 215$, it is natural for the employee and the plan sponsor to regard that amount as the correct cost of the pension promise. The employee may receive the pension promise in exchange for $\$ 215$ of direct pay rather than $\$ 377$. In this event, Ms. F is still forced to bear $\$ 162$ of uncompensated risk. But it is the employee rather than Mr. C who benefits at her expense.

Using an actuarial assumption that anticipates only a portion of the risk premium doesn't solve the problem. For example, using a $7 \%$ return assumption rather than $8 \%$ would raise the initial investment from $\$ 215$ to $\$ 258$. Because the $\$ 258$ is still expected to earn $8 \%$ annually, Ms. F would now expect to come out ahead relative to the $\$ 377$ bond/pension promise. But again recall that with her previously optimal portfolio, she had all the risk she wanted and was unwilling to exchange $\$ 377$ of bonds for $\$ 377$ of equity. $\$ 258$ of equity is clearly insufficient. 
She is still exposed to a risk that she wasn't previously bearing, and would need $\$ 377$ to be able to restore her original position.

Similarly, keeping Mr. C exposed for some period (but not the full 20 years) doesn't solve the problem. Ms. F must step into the shoes of Mr. C with enough money to cover the price of the hedging Treasury bond. Otherwise the expected rewards of her position are less than the market provides for the risk she is assuming, and she cannot execute a market transaction to remove the risk without digging into her own pockets.

So, our requirement of fairness between taxpayer generations forbids $\mathrm{Mr}$. $\mathrm{C}$ from anticipating risk premiums and requires him to fund the full $\$ 377$ value of the pension promise discounted at the riskless rate. Note that the unfairness stems from the amount funded, not the choice of investment. With the plan's \$377 invested in equities, Ms. F could accept the risk and the expected tax refund when the pension is paid, or she could hedge the risk in her own portfolio.

\subsection{Is Investing in Equity Advantageous After Paying the Full Riskless Plan Cost?}

Once the full $\$ 377$ cost is paid, is there any advantage in investing that money in equities? Mr. C cannot (fairly) benefit by anticipating risk premiums, but he can benefit from the risk premiums once they are earned. We can consider three cases here, depending on how Mr. C and Ms. F share the risks and rewards.

Case 1: A Single Generation. The simplest case occurs when our two taxpayers are the same person - that is, Mr. C will be around for the full 20 years and will absorb all gains and losses during that period.

We suppose that before the pension plan was set up (or before the plan sponsor decided to invest in equities rather than the Treasury bond), Mr. $\mathrm{C}$ had a personal portfolio of equities 
and bonds that was optimal for his risk preference. The pension fund has now added a leveraged equity position in which $\mathrm{Mr}$. C owes the $\$ 1,000$ future pension and owns the $\$ 377$ equity portfolio. To restore his previous optimal position, he must sell $\$ 377$ of equities from his personal portfolio and buy the hedging Treasury bond to cover the pension. His total portfolio is now back in its previous position, considering both the securities that he owns directly and his exposure to the pension fund.

Clearly Mr. C enjoys no direct profit from this overall restructuring. The pension fund gains or losses that he experiences would, without the restructuring, have occurred in his personal portfolio. (We consider some secondary effects in Section 3.)

Proponents of equity investment by public pension plans often assert that the long duration of the plans permits intergenerational risk-sharing that can take advantage of an alleged tendency of equity market risk to diminish over time. So for the next two cases, we return to our two-taxpayer structure, with Ms. F stepping into the shoes of Mr. C after some portion of the 20year plan lifetime.

Case 2: Immediate Recognition of Gains and Losses. First we suppose that the gains and losses are immediately covered by an adjustment in the taxes levied by the plan sponsor. Plan surplus (relative to the price of the hedging Treasury bond) is removed from the plan and refunded to the taxpayer du jour ${ }^{2}$. Deficits are corrected by immediate additional taxes.

With this immediate recognition, Mr. C would, while he remained responsible for the pension fund's gains and losses, be in the same position as in Case 1 above. He would offset the pension fund's leveraged equity holding by the opposite transaction in his personal portfolio, and his total portfolio would be unaffected by the pension fund's decision to invest in equities. 
Ms. F would also be unaffected. When she assumes responsibility for the pension plan, the plan's assets and liabilities would be equal and she could offset them in her personal portfolio.

Case 3: Spread Recognition of Gains and Losses. Now suppose that, under more conventional actuarial procedures, gains and losses are amortized over an extended period. For illustration, we assume amortization in equal installments (plus interest) over the 10 years following each year's gain or loss.

Let us temporarily suppose that the two taxpayers select a date for the handoff of responsibility for the pension plan, with no option on either side to back out and no compensation at that time for the condition of the pension fund. For illustration, we set the handoff date at 6 years from now.

When Mr. C leaves, then, $50 \%$ of the first-year gain or loss will have been paid off ( 5 years' worth of installments following the first-year occurrence). The remaining $50 \%$ becomes the responsibility of Ms. F. Mr. C will have amortized $40 \%$ of the second-year gain or loss, with $60 \%$ passing to Ms. F - and so forth.

Current Taxpayer Viewpoint. Does the spreading of gains and losses to Ms. F benefit Mr. $\mathrm{C}$ by reducing his downside risk on the equity performance? No! Because the spreading is symmetrical, his potential risk premiums are reduced in the same proportion as his risk. He will receive, eventually, $50 \%$ of the first-year gain or loss. With respect to that year, his situation is the same as if the fund held only $50 \%$ equity rather than $100 \%$ - and that is how he should adjust his personal portfolio if he wishes to offset the pension fund's equity exposure. With respect to the second year, he receives, eventually, $40 \%$ of the gain or loss; he can readjust his personal portfolio during the second year accordingly. 
Future Taxpayer Viewpoint. Ms. F's position is also fair at time zero. She will receive $50 \%$ of the first-year gain or loss, $60 \%$ of the second, etc. She can offset this exposure in her personal portfolio.

Handoff date not known in advance. Now suppose that Mr. C and Ms. F do not know the handoff date in advance, but agree that Ms. F will accept without compensation the surplus or deficit at the time of the handoff. Or, equivalently, suppose that Ms. F is replacing Mr. C without any financial dealings between them - for example, Ms. F is succeeding Mr. C as a renter. Then it is not clear in advance how much pension fund exposure is falling on each taxpayer, and they cannot accurately hedge their individual exposures. But, assuming that the amortization of gains and losses is symmetrical, Mr. C will ultimately realize a certain percentage of the risks taken during his tenure, and the identical percentage of the risk premiums earned. There is an intergenerational sharing of risk, and a commensurate sharing of rewards, so the arrangement is fair. But the sharing does not give the parties any better risk/reward balance than either could get alone in the capital markets.

The situation might be different if the handoff is not prearranged but simply a chance event that occurs, for example, when Ms. F buys Mr. C's home or business. With full transparency, we may suppose that the two taxpayers will recognize the value of future taxes associated with the pension plan in their sale negotiation. Then Mr. C can negotiate a higher sale price in recognition of pension surplus, or Ms. F can obtain a price concession in recognition of a pension deficit. In that situation, Mr. C has the full risks and rewards of the pension fund performance during his holding period, regardless of the gain/loss spreading used by the fund.

In practice, of course, there would be no explicit recognition of the pension plan condition in the sale of a home or business. Then Mr. C and Ms. F would be back in the situation 
where each bears a risk commensurate with his or her share of the rewards, and the equity investment conveys no advantage that they couldn't achieve in their personal portfolios. A pension deficit large enough to threaten the finances of the governmental sponsor, however, might get enough publicity to affect the sale price. Pension surplus is less likely to attract such attention. To the extent that Mr. C's home or business sale price is more likely to be charged for deficits than rewarded for surplus, pension fund equity market risk is unfavorable to $\mathrm{Mr}$. C.

Cases 2 and 3 show that the pension plan does not reduce equity risk by spreading it over a finite number of different taxpayer generations. Each generation must bear the risks that correspond to its potential risk premiums. If one bears a lesser share of risk than of risk premiums, another must bear more risk; there must be an intergenerational transfer of risk and therefore of value. The essential lesson here is the futility of trying to spread risk across generations for mutual reward.

Investing the pension fund in equities, then, provides no first-order gains (or losses) to all taxpayers in aggregate. In Section 3, we consider several second-order effects of pension fund equity market investment.

\section{Taxes and other second-order effects}

\subsection{Modeling the tax effects}

The main second-order effect of the pension fund's equity investment is to increase the taxpayer's Federal income taxes. The U.S. taxes bonds more highly than equities and gives corporations favorable tax treatment for pension funding. Under these conditions, Black (1980) and Tepper (1981) have shown that it is tax-efficient for corporations to fund their pension plans fully, to invest the pension fund in bonds, and to shift equity risk to the shareholders' own portfolios or elsewhere in the company. 
Because state and local governments are not subject to Federal income tax, it may appear that there is no tax advantage to investing their plans in bonds. Black's method involves corporate tax deductions and does not apply to governmental plans. But Tepper suggests that the pension fund asset allocation be offset by the shareholder, and a similar approach works for public plans. We show below that the taxpayer loses when the governmental pension plan invests in equities, forcing him to rebalance his overall equity exposure by shifting some of his personal portfolio from equities to bonds.

Notation and assumptions. We use the following notation and assumptions:

- The taxpayer pays Federal income taxes at an effective rate of $\tau_{b}$ on income from bonds and $\tau_{s}$ on equities. Generally, $\tau_{b}>\tau_{s}$, because capital gain tax rates are lower than ordinary tax rates and are not due before gains are realized; currently, dividends are also taxed below ordinary rates.

- The taxpayer deducts local taxes from Federal taxable income at a marginal rate of $\tau_{d}$ (For taxpayers who cannot deduct local taxes because they use the standard deduction or pay under the alternative minimum tax, $\tau_{d}$ is zero; otherwise it is generally equal to $\tau_{b}$.)

- The actual (stochastic) investment return is $s \tilde{r}_{s}$ on equities and $\tilde{r}_{b}$ on bonds.

- The pension fund shifts $\$ 1$ from bonds to equities.

- The taxpayer offsets the pension fund equity holdings by selling equities and buying bonds in his personal portfolio.

Here is the Federal income tax effect on the taxpayer of the overall transaction, reflecting his exposure to the pension fund and the offsetting change he should make in his personal portfolio. 


\begin{tabular}{|l|l|l|}
\hline \multicolumn{1}{|c|}{ Change in } & \multicolumn{1}{|c|}{ Pension Fund } & \multicolumn{1}{c|}{ Personal Portfolio } \\
\hline 1. Holdings & $+\$ 1$ equity $-\$ 1$ bonds & $(\$ 1 \text { bonds }-\$ 1 \text { equity })^{*}\left(1-\tau_{d}\right) /\left(1-\tau_{s}\right)$ \\
\hline 2. Total Return & $\tilde{r}_{s}-\tilde{r}_{b}$ & $\left(\tilde{r}_{b}-\tilde{r}_{s}\right)^{*}\left(1-\tau_{d}\right) /\left(1-\tau_{s}\right)$ \\
\hline $\begin{array}{l}\text { 3. After-tax Effect on } \\
\text { Taxpayer }\end{array}$ & $\left(1-\tau_{d}\right)^{*}\left(\tilde{r}_{s}-\tilde{r}_{b}\right)$ & {$\left[\left(1-\tau_{b}\right)^{*} \tilde{r}_{b}-\left(1-\tau_{s}\right) \tilde{r}_{s}\right]^{*}\left(1-\tau_{d}\right) /\left(1-\tau_{s}\right)$} \\
\hline 4. Total of Line 3 & $\tilde{r}_{b}\left(1-\tau_{d}\right)^{*}\left(\tau_{s}-\tau_{b}\right) /\left(1-\tau_{s}\right)$ \\
\hline
\end{tabular}

Line 1: The pension fund buys $\$ 1$ of equities and sells $\$ 1$ of bonds. The taxpayer responds by buying $\left(1-\tau_{d}\right) /\left(1-\tau_{s}\right)$ of equities and selling the same amount of bonds. The scaling factor (1$\left.\tau_{d}\right) /\left(1-\tau_{s}\right)$ reflects the different tax consequences to the taxpayer of gains in the pension fund and in his personal portfolio. This factor is calculated to leave the taxpayer's total after-tax equity exposure unchanged, as Line 4 will show.

Line 2: The pension fund earnings reflect $\$ 1$ of equities rather than $\$ 1$ of bonds. The taxpayer's personal account reflects the opposite effect, scaled by $\left(1-\tau_{d}\right) /\left(1-\tau_{s}\right)$.

Line 3: We adjust the pension fund earnings to reflect their after-tax cost or value to the taxpayer, whose local government tax (or rebate) for the pension fund is deductible (or taxable) on his Federal tax return. We similarly tax-adjust the change in his personal portfolio return.

Line 4: Note that $\tilde{r}_{s}$ does not appear. This shows that the taxpayer has hedged the pension fund transaction and restored his previous risk level. The total effect on the shareholder's net income is negative, because $\tau_{b}>\tau_{s}$ and the other factors are positive. (On a mark-to-market basis, $\tilde{r}_{b}$ may be negative in any one year, but on a hedging portfolio held to maturity it must be positive over its horizon.) 
This illustration shows that the taxpayer loses when the public plan invests in equities. The Internal Revenue Code provides a tax shelter for the taxpayer to fund the local pension plan, and the taxpayer would prefer to use that shelter for highly taxed securities like taxable bonds, not lightly taxed securities like municipal bonds or equities.

Note that this illustration assumes that the taxpayer experiences the full impact of any pension fund gains and losses - in other words, full exposure. If some portion of those gains and losses is borne by other taxpayer generations, the taxpayer should scale down the adjustment in his personal portfolio that offsets the pension fund equity investment. For example, if the taxpayer expects to bear half of the current year gain or loss, he should only adjust his personal portfolio by half the amount indicated in the table, and the tax disadvantage of the pension fund equity investment is halved.

\subsection{Other second-order effects}

Surplus Sharing. Another second-order effect that works against pension fund investment in equities is the potential for employee claims on plan surplus. In many public plans, employees make substantial contributions. Even the employer contributions are arguably their money from the start, representing deferrals of their compensation into the pension fund. Therefore, employees may contend, they are entitled to the lion's share of any investment gains, in the form of pension or salary increases.

Employers and taxpayers can respond that surplus produced by risk-taking should belong to the risk bearer, regardless of the source of the funds. With no default risk, taxpayers are bound to make up for any losses, so they should reap the rewards of any gains. On the other hand, there are instances in which employees have had to share the cost of disappointing investment performance, through higher employee contributions or benefit changes (such as COLA 
restrictions). Whatever its merits, the employees' claim to a share of the surplus has considerable traction and is often written explicitly in the pension plan.

We have shown that taxpayers have no preference in terms of gross investment returns between holding equities in their personal portfolio and holding them by proxy in the pension plan. In their personal portfolios, they bear all losses, and they have an undisputed claim to all gains. If they are fully responsible for pension fund losses, but have only a diluted share of the gains, they will have a strong preference for taking their equity exposure directly and their bond exposure in the pension fund.

Governmental Borrowing Cost. We have assumed that the pensions are not subject to default risk - a comfortable assumption based on the historical record. The debt of governmental entities below the Federal level, though, does carry credit risk, raising the debt service cost borne by taxpayers.

With the transparency that we assume, rating agencies and creditors should recognize that pension plan investment in the equity market increases the risk of the sponsor's bonds.

Governments whose pension plans invest in equities should expect to pay higher interest rates on their borrowing. There is no analogous effect for the taxpayer's personal investment in equities.

To the extent that creditors' recognition of the pension plan risk is impressionistic rather than explicit, an asymmetry may further argue against pension fund equity investment. As we observed in connection with the handoff between the current and future taxpayers, a large pension deficit would attract far more attention than a comparable surplus. The credit rating penalty of poor equity performance may far outweigh the reward of good performance. 
Indulgence in pension fund equity investment is particularly dangerous for local governments whose tax revenues are also tied closely to the performance of the equity markets. New York City is a prime example.

Access to Equity Investments. We have argued that taxpayers should not want their local governmental plan to invest in equities, because they can hold equities more efficiently through their personal portfolios. But some taxpayers may not have sufficient personal assets to invest.

It is likely, though, that taxpayers without investment assets should not be running equity risk through the public plan. These taxpayers are already heavily exposed to the equity markets, because their future employment income is likely to be quite sensitive to the same economic factors that affect the performance of the equity markets.

Pension Plan Put. We should mention one other second-order effect that differs between corporate and public pension plans. One advantage of equity investing by corporate pension funds is that it increases the value of the "pension plan put". This refers to the possibility that if the employer fails, pension plan losses will be absorbed not by the shareholders who stood to gain from the equity market risk, but by the Pension Benefit Guaranty Corporation or by participants (through reductions in their nonguaranteed pensions) ${ }^{3}$. Whatever the merits of this argument for corporate pension plan investment in equities - and they are dubious - they do not fit the public plan context, where there is no PBGC and (we have assumed) no defaults on pensions promised to employees.

\section{Obstacles to Investing Public Plans Exclusively in Bonds}

We have not touched on the many practical obstacles to all-bond investment by public funds, even if the theoretical argument is accepted. Future generations, who bear the risks of current policies, do not have current votes, and opaque accounting obscures the view of those 
who would do right by those future generations. Elected politicians of course prefer low taxes now, leaving the risk of tax increases as a problem for their successors.

Some of these obstacles are being cleared right now. The absence of transparency in pension plans is not an eternal fact of life; it is largely a matter of accounting rules. Projects currently underway at the FASB and IASB are likely to improve corporate pension accounting standards dramatically. The resulting transparency should facilitate a significant equity-to-bond shift in corporate pension plan assets during the next decade.

Both the transparency of corporate pension finance and the investment restructuring are certain to affect the public plan sector, even if the GASB does not respond quickly. The current low level of taxpayer focus on the financing of their public pension plans may not long endure, especially if they learn that they are giving away $\$ 377$ pensions for $\$ 215$.

\section{What should a public plan sponsor do about this today?}

Public plan sponsors need to understand the concepts developed in Section 2, which demonstrate that current actuarial costing methods are undervaluing promises made by public

plans to employees. With this understanding comes a dilemma. If the sponsor immediately shifts to bonds, or directs the plan's actuary to use near risk-free discount rates, the contribution demands on current taxpayers will skyrocket. If, on the other hand, business continues as usual, public employees will continue to trade small wage reductions for more valuable pension benefits.

A sponsor may want to stop giving pension bargains but may feel that the bargains already given cannot be paid for by ambushing current taxpayers. Fortunately for such a sponsor, the slow process that will begin with accounting changes in the private sector is not likely to be widely perceived in the public sector for a number of years. These years should be used to ease 
the pain. The sponsor who prioritizes stopping the largesse will put up strict barriers to benefit improvements for existing employees (other than those already attached to future service and salaries). Refusing to trade new benefits for anything less than their full value in wage concessions is the key. Where possible, establishing new tiers (effectively separate plans) for new hires should be considered. The new tier contributions may be invested in liability-matching bonds to justify, under current actuarial rules, full funding for these benefits. ${ }^{4}$

Today's taxpayers still need to share the historic under-pricing with future taxpayers by continuing the current mis-pricing of existing benefit promises through as long a transition period as the system will bear. A sponsor may anticipate the impact of future transparency by steadily shifting the asset allocation to bonds over an extended transition period. The key balancing act here is to be ahead of the curve compared to other public plans, not too far behind the private sector, and always attentive to the rising sun of transparency. Sponsors who act too swiftly may disrupt the contribution stability on which their overall taxing and spending plans rely, thereby shocking their financial position, discouraging employees and taxpayers and driving off new residents and businesses. Sponsors who delay too long may postpone the damage but will pay the price for giving away unaffordable promises and for holding equities at a time when vast amounts of other pension money were moving from equities to bonds.

\subsection{The "natural" pension investment}

Because equity has dominated public pension portfolios for many years, a shift to bonds is seen as a radical departure from the "natural" investment policy. But is equity really a more natural pension fund investment than bonds?

Suppose that a government is initially paying its employees all cash, with no pension plan. Then the government and employees negotiate a pension plan. Under the plan, the 
employees' salaries are reduced by specified amounts, with the reductions diverted to the pension fund. There they are invested in riskless liability-matching bonds, and the employees receive the proceeds when they retire - no more, no less. Clearly, taxpayers should be indifferent to the implementation of this plan; they are in exactly the same position they were in previously.

Now, suppose the government decides to swap the pension plan bonds for equities. This decision clearly changes the exposure of taxpayers from neutral to speculative. Given that taxpayers can make and implement this choice privately, we may well ask why taxpayers would want their government to do so for them.

\section{Conclusion}

Current funding and investment practices are costing taxpayers dearly. We are not directly addressing the losses of the past few years, which we can all hope are temporary, but the poor decision-making that stems from failure to understand the risks of equity investment. For example:

- Governments issue pension obligation bonds to capture what they mistakenly believe is an arbitrage gain from the excess of expected pension fund returns over their borrowing cost. There is no real economic gain, only some profits for investment bankers, lower costs for current taxpayers, and additional risk borne by future taxpayers (Gold 2000).

- Governments under-price employees' pensions by anticipating risk premiums, and they share “excess" risk premiums earned with employees, further loading risks onto taxpayers for which they stand to earn no rewards.

- Intergenerational risk-sharing is thwarted by each taxpayer generation's inclination to take winnings off the table and let the losses ride. 
Risk has a cost, a cost that is overlooked by current accounting and actuarial standards and therefore by most public plan stakeholders. Correct recognition of that cost would greatly alter much public plan practice and improve the lot of tomorrow's taxpayers. 


\section{References}

Bader, Lawrence N. 2003. "The Case Against Stock in Corporate Pension Funds," Pension Section News, February 2003.

Black, Fischer. 1980. “The Tax Consequences of Long-Run Pension Policy,” Financial Analysts Journal, July-August, pp. 21-30.

Gold, Jeremy. 2000. “Actuarial Assumptions for Pension Plans Invite Arbitrage - The Case of Pension Obligation Bonds," Risks and Rewards, September, pp. 6-7.

Peskin, Michael W. 2001. “Asset/Liability Management in the Public Sector,” in Pensions in thePublic Sector, eds. Olivia S. Mitchell and Edwin C. Hustead, University of Pennsylvania Press, Chapter 9, pp. 195-217.

Tepper, Irwin. 1981. “Taxation and Corporate Pension Policy”, Journal of Finance 36-1, March, pp. 1-13. 


\section{Endnotes}

${ }^{1}$ The Financial Accounting Standards Board (FASB) and the International Accounting Standards Board (IASB) are currently developing such pension accounting standards.

${ }^{2}$ More likely, surplus would not be removed from the plan but would be used to reduce contributions made in respect of future additional benefit accruals, reducing the taxes needed to support the plan.

${ }^{3}$ Sharpe (1976).

4 We recognize the danger that public employee groups may reject properly priced defined benefits in favor of inadequately understood defined contribution plans, based on the optimistic projections of the mutual fund industry. But mis-pricing defined benefits to compete with misrepresented defined contributions is not an appropriate response. 